\title{
Soil water repellency changes with depth and relationship to physical properties within wettable and repellent soil profiles
}

\author{
Nasrollah Sepehrnia ${ }^{1 *}$, Mohammad Ali Hajabbasi ${ }^{1}$, Majid Afyuni ${ }^{1}$, Lubomír Lichner ${ }^{2}$ \\ ${ }^{1}$ Department of Soil Science, College of Agriculture, Isfahan University of Technology, Isfahan, 84156-83111, Iran. \\ 2 Institute of Hydrology, Slovak Academy of Sciences, Dúbravská cesta 9, 84104 Bratislava, Slovakia. \\ ${ }^{*}$ Corresponding author. Tel.: +983133913471. Fax:+983133913471. E-mail: n.sepehrnia@ag.iut.ac.ir
}

\begin{abstract}
This study explored the effect of soil water repellency (SWR) on soil hydrophysical properties with depth. Soils were sampled from two distinctly wettable and water repellent soil profiles at depth increments from $0-60 \mathrm{~cm}$. The soils were selected because they appeared to either wet readily (wettable) or remain dry (water repellent) under field conditions. Basic soil properties (MWD, SOM, $\left.\theta_{v}\right)$ were compared to hydrophysical properties $\left(K_{s}, S_{w}, S_{e}, S_{w w}, S_{w h}\right.$, WDPT, $R I_{c}, R I_{m}$ and WRCT) that characterise or are affected by water repellency. Our results showed both soil and depth affected basic and hydrophysical properties of the soils $(\mathrm{p}<0.001)$. Soil organic matter $(\mathrm{SOM})$ was the major property responsible for water repellency at the selected depths (0-60). Water repellency changes affected moisture distribution and resulted in the upper layer $(0-40 \mathrm{~cm})$ of the repellent soil to be considerably drier compared to the wettable soil. The water repellent soil also had greater $\mathrm{MWD}_{\text {dry }}$ and $K_{s}$ over the entire $0-60 \mathrm{~cm}$ depth compared to the wettable soil. Various measures of sorptivity, $S_{w}, S_{e}, S_{w w}, S_{w h}$, were greater through the wettable than water repellent soil profile, which was also reflected in field and dry WDPT measurements. However, the wettable soil had subcritical water repellency, so the range of data was used to compare indices of water repellency. WRCT and $R I_{m}$ had less variation compared to WDPT and $R I_{c}$. Estimating water repellency using WRCT and $R I_{m}$ indicated that these indices can detect the degree of SWR and are able to better classify SWR degree of the subcritical-repellent soil from the wettable soil.
\end{abstract}

Keywords: Soil property; Soil organic matter; Aggregate; Bulk density; Mean weight diameter; Infiltration; Water repellency.

\section{INTRODUCTION}

Most soils express some level of water repellency at particular water contents (Bauters et al., 2000; Cosentino et al., 2010; Dekker et al., 2001; Doerr et al., 2007), but on wetting, water repellency often decreases with time (Cosentino et al., 2010; Lamparter et al., 2010) Thus, water repellency is a transient rather than permanent property of soil. The time that water repellency persists in soil can range from few seconds to weeks (Clothier et al., 2000), thereby having a great influence on water infiltration and solute transport (Dekker and Ritsema, 1994; Jarvis et al., 2008).

Since soil minerals are hydrophilic and wettable, repellency is generally attributed to soil organic matter (SOM) coating these minerals with hydrophobic compounds. SOM also influences other soil properties, particularly aggregation (Chenu et al., 2000; Hallett et al., 2001; Kodešová et al., 2009; Lal, 2011; Urbanek et al., 2014), so direct links between water repellency and SOM are difficult to disentangle. SOM influences other soil properties. In general, soil bulk density decreases linearly with increase in SOM content (Chaudhari et al., 2013; Haghighi et al., 2010), whereas porosity and macro-aggregation of soil increase with increase in SOM content (Eusufzai and Fujii, 2012). The decreased bulk density and increased porosity increase the water-holding capacity and infiltration of the soil, and decrease the potential for runoff, erosion, and evaporation (Shaver, 2010).

Persistence and severity of soil water repellency can be extremely variable and this has been extensively studied to compare impacts of different land uses, fire and vegetation (Beatty and Smith, 2014; Jordán et al., 2011; Lichner et al., 2012, 2013) on surface spatial variability (Diehl et al., 2014; Doerr et al., 2007; Orfánus et al., 2008). Depth dependent changes of SWR have been also investigated (Dekker et al., 2001), but studies on the variation of the extent and persistence of SWR and its relevance to hydrophysical properties throughout the soil profile are limited. Therefore, this study investigated the dependence of soil properties and SWR extent and persistence with depth. It allows an assessment of how SWR governs water flow and solute transport through the soil profile, and thus contributes to a more hydro-pedological understanding of soil profiles as stressed by Vogelmann et al. (2013).

\section{MATERIAL AND METHODS \\ Study site and sampling}

The field site was located in Shahrekord, the capital city of Chaharmahal and Bakhtiari Province, Iran. The study site $\left(32^{\circ}\right.$ $\left.19^{\prime} 16^{\prime \prime} \mathrm{N}, 50^{\circ} 46^{\prime} 26^{\prime \prime} \mathrm{E}\right)$ lies in a 700 ha area that has very poor vegetation (mostly mosses of Sphagnum genus), currently used as a pasture. Two plots, separated by a distance of $10 \mathrm{~m}$ formed the basis of our study. The water repellent soil from the first plot is classified as a Haplic Cambisol (degraded Histosol) (WRB, 2014) and had a silt loam texture (Soil Survey Division Staff, 1993). The sand, silt and clay contents were 9.12, 73.56, $17.32 \%$, respectively, $\mathrm{CaCO}_{3}$ content was $18.3 \%$, and $\mathrm{pH}$ (in $\mathrm{H}_{2} \mathrm{O}$ ) was 7.47 (mean values for the depths $0-30 \mathrm{~cm}$ ). The wettable soil from the second plot is also classified as a Haplic Cambisol (WRB, 2014), and has also a silt loam texture (Soil Survey Division Staff, 1993). The sand, silt and clay contents were $30.53,62.15$ and $5.32 \%$ respectively, $\mathrm{CaCO}_{3}$ content was $30.5 \%$, and $\mathrm{pH}$ (in $\mathrm{H}_{2} \mathrm{O}$ ) was 8.04 (mean values for the depths $0-30 \mathrm{~cm})$.

To obtain characteristics of the entire profile, samples were taken from 0-60 cm depth (0-10, 10-20, 20-30, 30-40, 40-50 and $50-60 \mathrm{~cm}$ ). Thirty aggregates (about $2 \mathrm{~cm} \times 2 \mathrm{~cm} \times 2 \mathrm{~cm}$ in 
size) were sampled at the studied plots and transported to the lab in closed containers to prevent evaporation. Thirty-six intact soil cores $(5 \mathrm{~cm}$ height $\times 5 \mathrm{~cm}$ diameter) were sampled using a hand auger from the depths of $0-60 \mathrm{~cm}$ in each soil and transported to the lab for infiltration experiments.

\section{Methods}

Bulk density, BD was determined by the core sampling method (Black and Hartge, 1986), mean weight diameter of aggregates from a bulk sample by the dry-sieving method (MWD ${ }_{\text {dry }}$ ) (Kemper and Chepil, 1965; Le Bissonnais, 1996), and total porosity was calculated from the bulk density and particle density, PD. Saturated hydraulic conductivity, $K_{s}$, was determined by the constant-head procedure (Klute and Dirksen, 1986). Total organic carbon (TOC) content was determined by the wet-digestion method (Walkly and Black, 1934), and SOM content was calculated as $\mathrm{SOM}=1.724$ TOC. Soil water content $\left(\theta_{v}\right)$ was measured in situ by a TDR instrument (Soil Moisture, 6050X1, Goleta, USA).

The persistence of water repellency was estimated with the WDPT test, conducted in the lab under controlled conditions (e.g., temperature $T=20^{\circ} \mathrm{C}$ and relative humidity $\mathrm{RH}=50 \%$ ). Field WDPT was measured on field-moist aggregates and the dry WDPT on aggregates dried at $65-70^{\circ} \mathrm{C}$ for 24 hours. Three drops of distilled water $(58 \pm 5 \mu \mathrm{L}$ in volume) were placed onto the soil surface from a standard height of $1 \mathrm{~cm}$ above the surface, and the time required for infiltration of each drop was recorded (Lichner et al., 2012).

The cumulative infiltration $I$ of both water and ethanol against the square root of time $t$ (SQRT $t$ ) was measured under a negative tension $h_{0}=-2 \mathrm{~cm}$ with a miniature infiltrometer that has an $2 \mathrm{~mm}$ diameter tip (Sepehrnia et al., 2016) on intact soil cores ( $5 \mathrm{~cm}$ high and $5 \mathrm{~cm}$ diameter). Infiltration, $I$ during early-time $(<180 \mathrm{~s})$ (Fig. 1) was used to calculate sorptivity, $S\left(h_{0}\right)$ by $S\left(h_{0}\right)=I / t^{1 / 2}$. Both the sorptivity of water, $S_{w}(-2 \mathrm{~cm})$, and the sorptivity of ethanol, $S_{e}(-2 \mathrm{~cm})$, were estimated for 3 replicates from each depth. The soil water repellency index, $R I$, was calculated using the equation (Tillman et al., 1989):

$R I=1.95 S_{e}(-2 \mathrm{~cm}) / S_{w}(-2 \mathrm{~cm})$

In this study, $R I$ was calculated from all the pairs of $S_{w}(-2 \mathrm{~cm})$ and $S_{e}(-2 \mathrm{~cm})$ values with the method presented by Pekárová et al. (2015). We refer to this as the combined soil water repellency index, $R I_{c}$.

As can be seen in Fig. 1, infiltration had a characteristic 'hockey-stick' shape, where the rate increased over time. The water sorptivity $S_{w h}(-2 \mathrm{~cm})$ for the hydrophobic state of the crust was estimated from the shallow slope of "hockey-sticklike" relationship at the onset of wetting. The water sorptivity $S_{w w}(-2 \mathrm{~cm})$ for nearly wettable state of the crust was estimated from the slope of this relationship after a longer time of infiltration (a straight line, representing the steeper part of hockeystick). The water repellency cessation time, WRCT was estimated from the point of intersection of these two straight lines, representing the hydrophobic and nearly wettable states of the crust.

With these data we calculated the modified soil water repellency index, $R I_{m}$ proposed by Lichner et al. (2013). This overcomes the limitations of the traditional approach since information on both the hydrophobic and the wettable states of soil are gathered. $R I_{m}$ was calculated using equation:

$R I_{m}=S_{w w}(-2 \mathrm{~cm}) / S_{w h}(-2 \mathrm{~cm})$

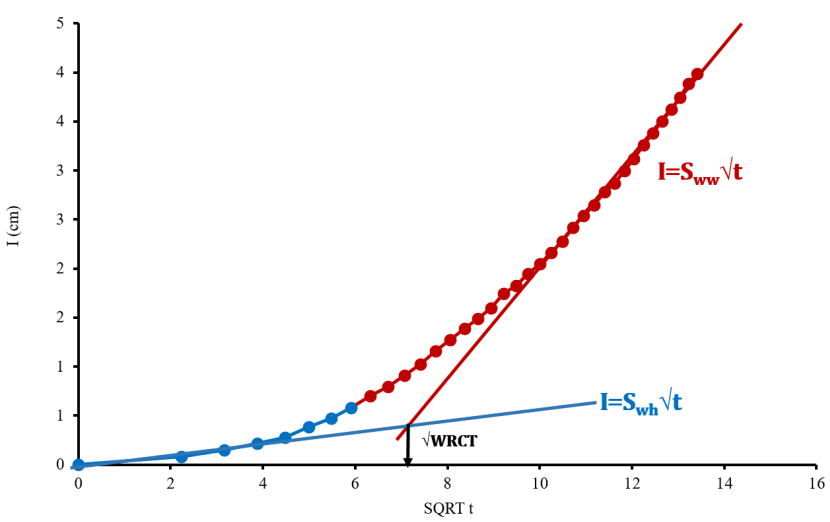

Fig. 1. "Hockey-stick-like" relationship of the cumulative infiltration of water $(I)$ against the square root of time $t$ (SQRT $t$ ) for the repellent soil. The water repellency cessation time (WRCT) was estimated from the point of the intersection of two straight lines, representing the $I=\mathrm{f}(\mathrm{SQRT} t)$ relationships for hydrophobic and nearly wettable states of the crust (Modified from Lichner et al., 2013).

\section{Statistical analysis}

The experiment was performed using a complete randomized design with three replicates for all variables. The type of soil (wettable and repellent), and the soil depths (0-10, 10-20, 20-30, 30-40, 40-50, and 50-60 cm) were the independent variables. The studied dependent parameters, some of which were not normally distributed, were normalized using different techniques (e.g. $\log 10$, exp, and/or Ln) and checked by the Shapiro-Wilk test. Then, statistical analyses were done using two-way ANOVA (Statistical Analysis System, SAS) and the post-hoc mean comparisons were performed by the LSD test (SAS Institute, 2004).

\section{RESULTS AND DISCUSSION}

Hydrophysical properties of the soils are presented in Table 1 and Figures 2 to 5 . These relatively undisturbed pasture soils had low bulk and particle densities (BD and PD, respectively) for both wettable and repellent soils (i.e. depth of $30-40 \mathrm{~cm}$ ). Clothier et al. (2000) also reported low BD values for water repellent soils with high organic matter, although we also found low BD for the wettable soil with less organic matter. Nesper et al. (2015) also reported low BD values for a productive pasture soil. The calculated porosity (i.e. 55\% for the depth of 30-40) was closely correlated with the saturated water content (i.e. 59\% for the depth of 30-40, not presented).

The organic matter of the repellent soil was higher than the wettable soil throughout the depth of the soil profile. Sepehrnia et al. (2016) studied these soils and reported SOM was associated with water repellency $(\mathrm{p}<0.01)$ at the selected depths, with greatest SOM found where water repellency values were largest. It has been suggested that the relationship between water repellency and SOM is a two-way mechanism, as SOM enhances water repellency of soils, and water repellency protects SOM against microbial decomposition (Goebel et al., 2011). A positive correlation between SOM and both the degree and persistence of water repellency was also found by Leelamanie (2014). However, a negative correlation as well as no correlation has also been reported (Doerr et al., 2000). The explanation for this inconsistency may be that the small amount of hydrophobic compounds necessary to cause water repellency 
Table 1. Properties of soils from both repellent and wettable plots. The results are presented in the form of arithmetic mean \pm standard deviation.

\begin{tabular}{|c|c|c|c|c|c|c|c|}
\hline \multirow[b]{2}{*}{ Soil } & \multirow{2}{*}{ Attribute } & \multicolumn{6}{|c|}{ Depth (cm) } \\
\hline & & $0-10$ & $10-20$ & $20-30$ & $30-40$ & $40-50$ & $50-60$ \\
\hline \multirow{11}{*}{ Repellent } & $\mathrm{BD}\left(\mathrm{g} \mathrm{cm}^{-3}\right)$ & $1.05 \pm 0.05^{\mathrm{d}}$ & $1.12 \pm 0.01^{\mathrm{c}}$ & $1.10 \pm 0.006^{\mathrm{c}}$ & $0.94^{\mathrm{e}}$ & $1.30 \pm 0.02^{\mathrm{b}}$ & $1.34 \pm 0.02^{\mathrm{a}}$ \\
\hline & $\mathrm{PD}\left(\mathrm{g} \mathrm{cm}^{-3}\right)$ & $2.10^{\mathrm{c}}$ & $2.10^{\mathrm{c}}$ & $2.10^{\mathrm{c}}$ & $2.10^{\mathrm{c}}$ & $2.40^{\mathrm{b}}$ & $2.53^{\mathrm{a}}$ \\
\hline & $P$ & $0.50^{\mathrm{b}}$ & $0.47^{\mathrm{bc}}$ & $0.48^{\mathrm{cb}}$ & $0.55^{\mathrm{a}}$ & $0.46^{\mathrm{c}}$ & $0.47^{\mathrm{cb}}$ \\
\hline & $\operatorname{SOM}(\%)$ & $7.50 \pm 0.36^{\mathrm{b}}$ & $7.77 \pm 0.06^{\mathrm{b}}$ & $7.47 \pm 0.31^{\mathrm{b}}$ & $8.50 \pm 0.26^{\mathrm{a}}$ & $2.3 \pm 0.10^{\mathrm{c}}$ & $0.53 \pm 0.07^{\mathrm{d}}$ \\
\hline & $\theta_{v}\left(\mathrm{~cm}^{3} 100 \mathrm{~cm}^{-3}\right)$ & $0.00^{\mathrm{d}}$ & $0.11 \pm 0.006^{\mathrm{d}}$ & $1.10 \pm 0.10^{\mathrm{c}}$ & $5.60 \pm 0.1^{\mathrm{b}}$ & $16.40 \pm 0.20^{\mathrm{a}}$ & $16.40^{\mathrm{a}}$ \\
\hline & $\mathrm{MWD}_{\text {dry }}(\mathrm{mm})$ & $0.87 \pm 0.02^{\mathrm{d}}$ & $3.40 \pm 0.10^{\mathrm{a}}$ & $3.43 \pm 0.11^{\mathrm{a}}$ & $3.43 \pm 0.11^{\mathrm{a}}$ & $3.13 \pm 0.06^{\mathrm{b}}$ & $2.93 \pm 0.03^{\mathrm{c}}$ \\
\hline & $S_{w}\left(\mathrm{~cm} \mathrm{~s}^{-0.5}\right)$ & $0.34 \pm 0.02^{b}$ & $0.20 \pm 0.01^{\mathrm{b}}$ & $0.25^{\mathrm{b}}$ & $0.008 \pm 0.001^{\mathrm{c}}$ & $0.31 \pm 0.13 b$ & $1.01 \pm 0.23^{\mathrm{a}}$ \\
\hline & $S_{e}\left(\mathrm{~cm} \mathrm{~s}^{-0.5}\right)$ & $0.77 \pm 0.06^{\mathrm{b}}$ & $0.77 \pm 0.06^{\mathrm{b}}$ & $0.72^{\mathrm{c}}$ & $1.14^{\mathrm{a}}$ & $0.22^{\mathrm{e}}$ & $0.32^{\mathrm{d}}$ \\
\hline & $S_{w w}\left(\mathrm{~cm} \mathrm{~s}^{-0.5}\right)$ & $0.64 \pm 0.11^{\mathrm{bc}}$ & $0.360 \pm 0.06^{\text {cd }}$ & $0.38 \pm 0.06^{\mathrm{cd}}$ & $0.047 \pm 0.023^{\mathrm{d}}$ & $0.995 \pm 0.65^{\mathrm{ab}}$ & $1.32 \pm 0.46^{\mathrm{a}}$ \\
\hline & $S_{w h}\left(\mathrm{~cm} \mathrm{~s}^{-0.5}\right)$ & $0.188 \pm 0.04^{\mathrm{bc}}$ & $0.074 \pm 0.02^{\mathrm{cd}}$ & $0.115 \pm 0.02 b^{\mathrm{cd}}$ & $0.008 \pm 0.001^{\mathrm{d}}$ & $0.21 \pm 0.10^{\mathrm{b}}$ & $0.402 \pm 0.13^{\mathrm{a}}$ \\
\hline & $K_{s}\left(\mathrm{~cm} \mathrm{~min}^{-1}\right)$ & $0.28 \pm 0.003^{\mathrm{c}}$ & $0.63 \pm 0.01^{\mathrm{b}}$ & $0.098 \pm 0.003^{\mathrm{d}}$ & $0.99 \pm 0.007^{\mathrm{a}}$ & $0.10 \pm 0.002^{\mathrm{d}}$ & $0.08 \pm 0.003^{\mathrm{e}}$ \\
\hline \multirow{11}{*}{ Wettable } & $\mathrm{BD}\left(\mathrm{g} \mathrm{cm}^{-3}\right)$ & $1.08 \pm 0.06^{\mathrm{c}}$ & $1.14 \pm 0.05^{\mathrm{ab}}$ & $1.09 \pm 0.01^{\mathrm{c}}$ & $1.10 \pm 0.01^{\mathrm{cb}}$ & $1.13 \pm 0.01^{\mathrm{abc}}$ & $1.20 \pm 0.01^{\mathrm{a}}$ \\
\hline & $\mathrm{PD}\left(\mathrm{g} \mathrm{cm}^{-3}\right)$ & $2.45^{\mathrm{e}}$ & $2.48^{\mathrm{de}}$ & $2.51^{\mathrm{dc}}$ & $2.53^{\mathrm{cb}}$ & $2.57^{\mathrm{a}}$ & $2.55^{\mathrm{ab}}$ \\
\hline & $P$ & $0.56^{\mathrm{a}}$ & $0.54^{\mathrm{a}}$ & $0.56^{\mathrm{a}}$ & $0.56^{\mathrm{a}}$ & $0.56^{\mathrm{a}}$ & $0.55^{\mathrm{a}}$ \\
\hline & $\operatorname{SOM}(\%)$ & $1.81 \pm 0.06^{\mathrm{a}}$ & $1.21 \pm 0.1^{\mathrm{b}}$ & $0.55 \pm 0.08^{\mathrm{c}}$ & $0.55 \pm 0.09^{c}$ & $0.53 \pm 0.05^{\mathrm{c}}$ & $0.53 \pm 0.12^{\mathrm{c}}$ \\
\hline & $\theta_{v}\left(\mathrm{~cm}^{3} 100 \mathrm{~cm}^{-3}\right)$ & $0.00^{\mathrm{e}}$ & $4.23 \pm 0.15^{\mathrm{d}}$ & $10.50 \pm 0.25^{\mathrm{c}}$ & $13.04 \pm 0.17^{\mathrm{b}}$ & $18.60 \pm 0.09^{\mathrm{a}}$ & $18.60 \pm 0.07^{\mathrm{a}}$ \\
\hline & $\mathrm{MWD}_{\text {dry }}(\mathrm{mm})$ & $1.60 \pm 0.05^{\mathrm{d}}$ & $1.88 \pm 0.41^{\mathrm{c}}$ & $1.89 \pm 0.03^{\mathrm{c}}$ & $2.36 \pm 0.03^{\mathrm{b}}$ & $2.35 \pm 0.002^{\mathrm{b}}$ & $2.50 \pm 0.01^{\mathrm{b}}$ \\
\hline & $S_{w}\left(\mathrm{~cm} \mathrm{~s}^{-0.5}\right)$ & $1.39 \pm 0.20^{\mathrm{b}}$ & $1.58 \pm 0.57^{\mathrm{b}}$ & $3.29 \pm 0.44^{\mathrm{ab}}$ & $1.13 \pm 0.02^{\mathrm{b}}$ & $1.52 \pm 0.1^{\mathrm{b}}$ & $5.22 \pm 3.50^{\mathrm{a}}$ \\
\hline & $S_{e}\left(\mathrm{~cm} \mathrm{~s}^{-0.5}\right)$ & $1.63 \pm 0.46^{\mathrm{ab}}$ & $1.46 \pm 0.61^{\mathrm{ab}}$ & $1.49 \pm 0.21^{\mathrm{ab}}$ & $0.93^{\mathrm{b}}$ & $0.870 \pm 0.28^{\mathrm{b}}$ & $2.60 \pm 1.44^{\mathrm{a}}$ \\
\hline & $S_{w w}\left(\mathrm{~cm} \mathrm{~s}^{-0.5}\right.$ & $1.99 \pm 0.53^{\mathrm{cb}}$ & $2.02 \pm 0.51^{\mathrm{cb}}$ & $3.65 \pm 0.49^{\mathrm{a}}$ & $1.55 \pm 0.18^{\mathrm{c}}$ & $2.02 \pm 0.13^{\mathrm{cb}}$ & $3.04 \pm 1.38^{\mathrm{ab}}$ \\
\hline & $S_{w h}\left(\mathrm{~cm} \mathrm{~s}^{-0.5}\right)$ & $0.78 \pm 0.22^{\mathrm{b}}$ & $0.74 \pm 0.05^{\mathrm{b}}$ & $2.12 \pm 0.52^{\mathrm{a}}$ & $0.59 \pm 0.19^{b}$ & $0.81 \pm 0.05^{\mathrm{b}}$ & $2.53 \pm 1.20^{\mathrm{a}}$ \\
\hline & $K_{s}\left(\mathrm{~cm} \mathrm{~min}^{-1}\right)$ & $0.33 \pm 0.001^{\mathrm{b}}$ & $0.28 \pm 0.01^{\mathrm{c}}$ & $0.6 \pm 0.01^{\mathrm{a}}$ & $0.15 \pm 0.001^{\mathrm{d}}$ & $0.34 \pm 0.01^{\mathrm{b}}$ & $0.04 \pm 0.001^{\mathrm{e}}$ \\
\hline
\end{tabular}

BD: bulk density, PD: particle density, $p$ : porosity, SOM: soil organic matter, $\theta_{v}$ : volumetric water content, MWD: mean weight diameter, $S_{w}$ : water sorptivity, $S_{e}$ : intrinsic sorptivity, $S_{w h}$ : water sorptivity of hydrophobic state, $S_{w w}$ : water sorptivity of nearly wettable state. $K_{s}$ : saturated hydraulic conductivity. The same letters indicate that properties are not significantly different between depths at a significance level 0.01 .

is not proportional to the actual amount of organic matter present in soil (Wallis and Horne, 1992). Since organic matter may either cover the mineral grains as thin coatings or exist as adsorbed nano-sized microaggregates, a high spatial variability of SWR can be expected at small scales (Bachmann et al., 2013).

The wettable soil had a greater $\theta_{v}$ than the water repellent soil for $0-30$ depth of the soil profile $(\mathrm{P}<0.05)$, with the most severe SWR associated with the driest soil. Vogelmann et al. (2013) also reported SWR decreased sharply with an increase in water content. In spite of the differences in the upper part of

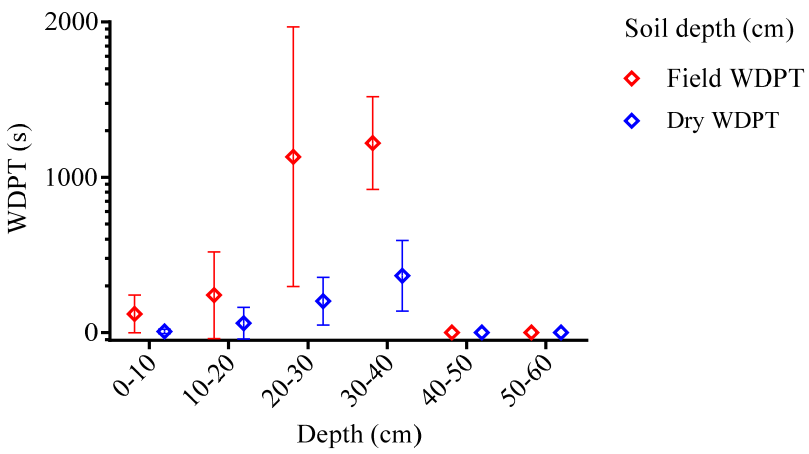

Fig. 2. Field and dry water drop penetration time (WDPT) for aggregates from the water-repellent field soil profile $(0-60 \mathrm{~cm})$. Data are presented as mean and standard deviation of thirty replicates. the soil profiles $(0-30 \mathrm{~cm})$, there was little difference between water content of both repellent and wettable soils below the depth of $30 \mathrm{~cm}$ (Table 4 and 5). This result might be due to evaporation from soil caused by a water repellent surface (Hallett, 2008). Keizer et al. (2007) also found that the transient wetting behavior of soil changed significantly due to the increase in soil water content from hydrophobic to hydrophilic within short time periods. Furthermore, Bachmann et al. (2007) have suggested that the water content where the hydrophobic medium becomes wettable with increasing moisture content,

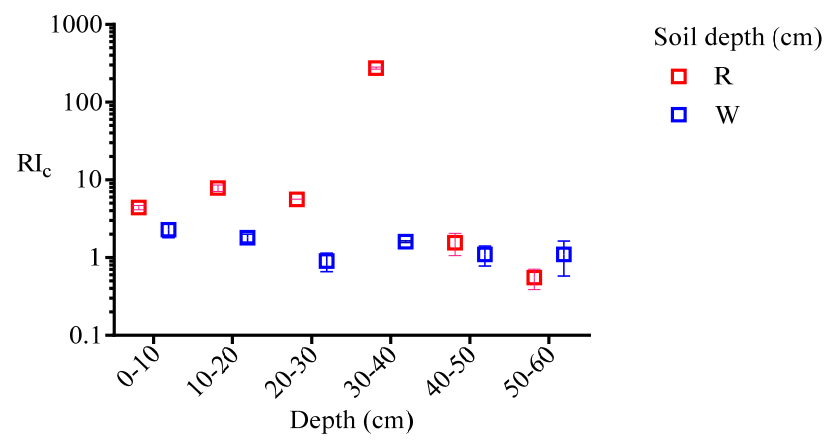

Fig. 3. Combined soil water repellency index $\left(R I_{c}\right)$ for the repellent and wettable field-soils at the studied depths $(0-60 \mathrm{~cm})$. ' $R$ ' and 'W' denote repellent and wettable soils, respectively. Data are presented as mean and standard deviation of three replicates. 


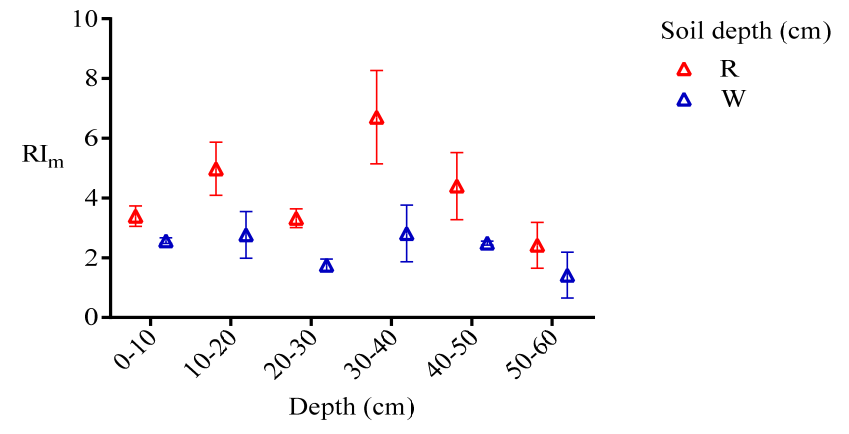

Fig. 4. Modified soil water repellency index $\left(R I_{m}\right)$ for the water repellent and wettable soils at the studied depths. ' $\mathrm{R}$ ' and ' $\mathrm{W}$ ' denote the repellent and wettable field soils, respectively. Data are presented as mean and standard deviation of three replicates.

increases with SOM content. Therefore, SOM has a transient impact on water repellency, rendering soil hydrophobic when drier than a certain water content, but wettable after long periods in contact with water.

$\mathrm{MWD}_{\text {dry }}$ of the repellent and wettable soils is presented in Table 1. The repellent soil had greater $\mathrm{MWD}_{\text {dry }}$ than the wettable soil at all depths except at the surface $(0-10 \mathrm{~cm})$. Various factors affect soil aggregate stability (Amezketa, 1999; Sepehrnia et al., 2014; Zamani et al., 2016) but such distinct differences in $\mathrm{MWD}_{\mathrm{dry}}$, small $\mathrm{BD}$, and hydrophobicity can be due to multiple effects of organic matter (Table 1). One driver is the coating of hydrophobic materials around the repellent soil aggregates that would decrease slaking stresses due to a slower inflow of water upon wetting. Vogelmann et al (2013) concluded cohesive forces between the particles of the hydrophobic aggregates act for a long period as a result of slow wetting and lead to an increase in geometric mean diameter, a stability index of water stable aggregates in wet-sieving. The $\mathrm{MWD}_{\mathrm{dry}}$ was greater for the repellent soil from 10-40 cm depth, where it also showed the greatest water repellency in comparison to the wettable soil. Water repellency, however, is not the only driver of soil aggregate stability.

Texture has a large impact and the results from $>40 \mathrm{~cm}$ between the two soils show similar water repellency and organic matter, but slightly greater aggregate stability for the water repellent soil with its silt loam texture, compared to the repellent soil with the silty clay texture. Silty soil textures are susceptible to soil management and erosion, as reflected in the small MWD dry values observed.

Most of the hydrophysical variables measured were more irregular throughout the soil profile for the repellent soil compared to the wettable soil. A very interesting finding was the high $K_{s}$ value of the repellent soil at the depth of $30-40 \mathrm{~cm}$, despite this also being where the greatest water repellency was observed. This is likely due to the transient nature of water repellency, as reflected in the WRCT results, and possibly due to the good continuity of pores resulting from greater aggregate stability where greater SOM and water repellency were observed. $K_{s}$ of both wettable and repellent soils decreased markedly at a depth of 50-60 cm. Lamparter et al. (2010) reported hydraulic conductivity of water can be predicted as a function of the SWR (evaluated using contact angle), but our findings do not support this. This shows the wettability states of soil surfaces change with time and are completely complicated and influenced by SWR (Clothier et al., 2000). Orfánus et al. (2014) reported both sorptivity and early-stage infiltration capacity decreased with increasing water repellency.

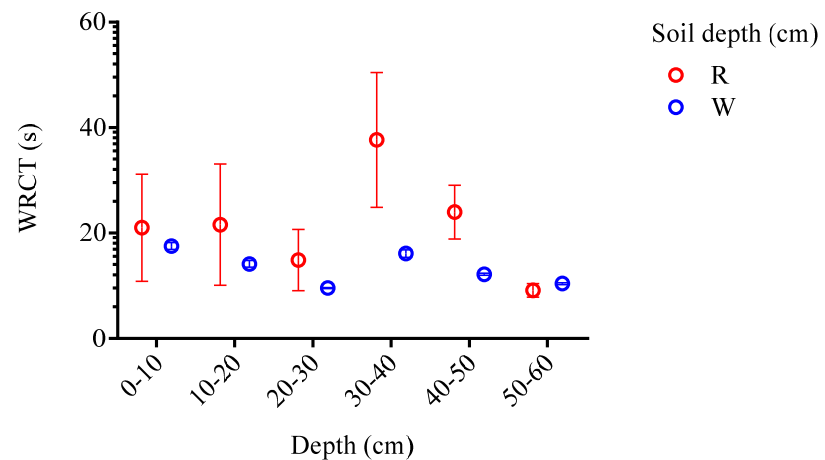

Fig. 5. Water repellency cessation time (WRCT) for the water repellent and wettable field soils at the studied depths. ' $R$ ' and ' $W$ ' denote the repellent and wettable field soils, respectively. Data are presented as mean and standard deviation of three replicates.

ANOVA showed that the studied depths of repellent soil significantly affected field and dry WDPT, $R I_{c}, R I_{m},(\mathrm{p}<0.001)$ and WRCT $(\mathrm{p}<0.05)$. However, no significant differences were observed for $R I_{c}, R I_{m}$, and WRCT for different depths of the wettable soil. The data are presented as mean and standard deviation in Figs. 2 to 5. Field and dry WDPT related to the repellent soil are shown in Fig 2. The wettable soil showed no signs of repellency using this test (WDPT $<5 \mathrm{~s}$ ) and thus the data are not shown. The severity of both actual and potential repellency in the repellent soil profile increased with depth towards $40 \mathrm{~cm}$, with the most dramatic increase at $20-40 \mathrm{~cm}$ depth $(\mathrm{p}<0.001)$. No repellency was observed at $40-60 \mathrm{~cm}$ depth (Fig. 2). Dekker et al. (2001), Täumer et al. (2005) and Bachmann et al. (2013) also reported spatial variation of SWR using WDPT through the soil profile. Johnson et al. (2005) and Madsen et al. (2011) found the variability of SWR was large in both time and space, which commonly attributed to the water content (Doerr et al., 2007; Hallett, 2008). The values of actual SWR were greater than our measure of potential SWR at all depths of the repellent field-soil. Dekker et al. (2001) examined 2580 soil samples for actual and potential SWR at depths of 0 $19 \mathrm{~cm}$ to assess the effects of water content, temperature, and season. They also found that actual SWR was more severe than potential SWR in some samples.

The combined repellency index $\left(R I_{c}\right)$ illustrated that the surface depths of the wettable soil exhibited SWR $(R I>1.95$, Fig. 3 ), although no sign of SWR was observed using the WDPTtest. This shows the high variability and poor sensitivity of the WDPT-method, which is caused by the unsteady-state sorptivity of water due to the small water drop size and heterogeneous distribution of hydrophobic material around soil particles (Cosentino et al., 2010). The $R I_{c}$ of the repellent soil was greater than the wettable field-soil in the upper profile $(0-40 \mathrm{~cm})$, but the $R I_{c}$ discrepancies decreased for the rest of the profile layers where both soils were more wettable. This is also reflected in the decreased organic matter content.

$R I_{m}\left(=S_{w w} / S_{w h}\right)$ was calculated and presented in Fig. 4. In comparison to WDPT and $R I_{c}$ (Fig. 2 and 3), the difference of $R I_{m}$ between the wettable and repellent soil, and between depths in the soil profile, was less (Fig. 4). Nevertheless, $R I_{m}$ values were greater for repellent than wettable soil at all depths $(\mathrm{P}<0.05)$. Water repellency of the soil profiles found by $R I_{m}$ followed a ranking to those found using $R I_{c}$ and WDPT, however, normal distribution was seen for $R I_{m}$ through the soil profiles. Moreover, $R I_{m}$ indicated that there were no significant differences between water repellency of the subsurface layers $(40-60 \mathrm{~cm})$ of the repellent soil and the layers of the wettable 
soil $(0-60 \mathrm{~cm})$. In other words, $R I_{m}$ showed the wettable soil could be potentially water repellent and classified as a subcritical water repellent soil. This is not surprising, because most soils are classified as subcritical water repellent around the world (Müller and Deurer, 2011). However, WDPT, and preferentially $R I_{c}$, did not illustrate whether some of the studied depths were wettable while others were subcritical water repellent. There was no significant difference between the estimated WRCTs with depth in the wettable field-soil profile (Fig. 5). WRCT was far more sensitive than WDPT, so it could offer an improved approach to quantify water repellency persistence of sub-critically water repellent soils. Goebel et al. (2005) also found slight wetting resistance (subcritical water repellency) in all samples using the capillary rise method, while, results by WDPT showed all samples seemed to be completely wettable. Moreover, the variability of SWR methods in terms of coefficients of variation had the order A-WDPT/P-WDPT $>>R I>R I_{m}$.

\section{CONCLUSION}

The results showed both soil and depth affected hydrophysical properties. The variations of MWD, SOM, $\theta_{v}$ as basic physical and, $S_{w}, S_{e}, S_{w w}, S_{w h}$, WDPT, $R I_{c}, R I_{m}$ as hydrophysical properties were more influenced by water repellency through the repellent soil compared to the wettable soil. WRCT assessment of SWR indices, as methods to detect persistence and severity, illustrated that WDPT and $R I_{c}$ variations were greater than $R I_{m}$. Although similar trends were found for the SWR indices, $R I_{m}$ was less variable through soil profiles. This study showed two advantages of the $R I_{m}\left(S_{w w} / S_{w h}\right)$ approach compared to the WDPT and $R I_{c}$ as follows: i) normal distribution of $R I_{m}$ through both soil profiles, which had different wettability behavior (proved by $R I_{c}$ and WDPT), provided a better description of the SWR state ii) better determination of real and subcritical repellent soils using WRCT, which is measured directly from the $R I_{m}$-curves.

Acknowledgement. This contribution was supported by the Isfahan University of Technology, Iran and the Scientific Grant Agency VEGA Project No. 2/0054/14. The authors thank Prof. Paul D. Hallett for his constructive comments.

\section{REFERENCES}

Amezketa, E., 1999. Soil aggregate stability: a review. J. Sustain. Agric., 14, 83-151.

Bachmann, J., Deurer, M., Arye, G., 2007. Water-repellent soil: 1. Development of a contact angle-dependent waterretention model. Vadose Zone J., 6, 436-445.

Bachmann, J., Goebel M.-O., Woche S.K., 2013. Small-scale contact angle mapping on undisturbed soil surfaces. J. Hydrol. Hydromech., 61, 3-8.

Bauters, T.W.J., Steenhuisa T.S., DiCarlo, D.A., Nieber, J.L., Dekker, L.W., Ritsema, C.J., Parlange, J.Y., Haverkamp, R. 2000. Physics of water repellent soils. J. Hydrol., 231-232: 233-243.

Beatty, S.M., Smith, J.E., 2014. Infiltration of water and ethanol solutions in water repellent post wildfire soils. J. Hydrol, 514: 233-248.

Black, G.R., Hartge, K.H., 1986. Bulk density. In: Klute A. (Ed.): Methods of Soil Analysis. Part 1. Physical and Mineralogical Methods. 2nd ed. ASA/SSSA Monograph 9(1), Madison, WI, USA, pp. 374-380.

Chaudhari, P.R., Ahire, D.V., Ahire, V.D., Chkravarty, M., Maity, S., 2013. Soil bulk density as related to soil texture, organic matter content and available total nutrients of Coimbatore soil. International Journal of Scientific and Research Publications, 3, 1-8.

Chenu, C., Le Bissonnais, Y., Arrouays, D., 2000. Organic matter influence on clay wettability and soil aggregate stability. Soil Sci. Soc. Am. J., 64, 1479-1486.

Clothier, B.E., Vogeler, I., Magesan, G.N., 2000. The breakdown of water repellency and solute transport through a hydrophobic soil. J. Hydrol., 231-232, 255-264.

Cosentino, D., Hallett, P.D., Michel, J.C., Chenu, C., 2010. Do different methods for measuring the hydrophobicity of soil aggregates give the same trends in soil amended with residue? Geoderma, 159, 221-227.

Dekker, L.W., Ritsema, C.J., 1994. How water moves in a water repellent sandy soil: potential and actual water repellency. Water Resour. Res., 30, 2507-2517.

Dekker, L.W., Doerr, S.H., Oostindie, K., Ziogas, A.K., Ritsema, C.J., 2001. Water repellency and critical soil water content in a dune sand. Soil. Sci. Soc. Am. J., 65, 16671674.

Diehl, D., Schneckenburger, T., Krüger, J., Goebel, M.-O., Woche, S.K., Schwarz, J., Shchegolikhina, A., Lang, F., Marschner, B., Thiele-Bruhn, S., Bachmann, J., Schaumann, G.E., 2014. Effect of multivalent cations, temperature and aging on soil organic matter interfacial properties. Environ. Chem., 11, 709-718.

Doerr, S.H., Shakesby, R.A.,Walsh, R.P.D., 2000. Soil water repellency: its causes, characteristics and hydrogeomorphological significance. Earth-Science Reviews, 51, 33-65.

Doerr, S.H., Ritsema, C.J., Dekker, L.W., Scott, D.F., Carter, D., 2007. Water repellence of soils: new insights and emerging research needs. Hydrol. Process., 21, 2223-2228.

Eusufzai, M.K., Fujii, K., 2012. Effect of organic matter amendment on hydraulic and pore characteristics of a clay loam soil. Open Journal of Soil Science, 2, 372-381.

Goebel, M.-O., Bachmann, J., Woche, S.K., Fischer, W.R., 2005. Soil wettability, aggregate stability, and the decomposition of soil organic matter. Geoderma, 128, 80-93.

Goebel, M.-O., Bachmann, J., Reichstein, M., Janssens, I.A., Guggenberger, G., 2011. Soil water repellency and its implications for organic matter decomposition - is there a link to extreme climatic events? Global Change Biol., 17, 26402656.

Haghighi, F., Gorji, M., Shorafa, M., 2010. A study of the effects of land use changes on soil physical properties and organic matter. Land Degrad. Develop., 21, 496-502.

Hallett, P.D., 2008. A brief overview of the causes, impacts and amelioration of soil water repellency - a review. Soil and Water Research, 3, S21-S29.

Hallett, P.D., Baumgartl, T., Young, I.M., 2001. Subcritical water repellency of aggregates from a range of soil management practices. Soil Sci. Soc. Am. J., 65, 184-190.

Jarvis, N., Etana, A., Stagnitti, F., 2008. Water repellency, nearsaturated infiltration and preferential solute transport in a macroporous clay soil. Geoderma, 143, 223-230.

Johnson, M.S., Lehmann, J., Steenhuis, T.S., Oliveira, L.V., Fernandes, E.C.M., 2005. Spatial and temporal variability of soil water repellency of Amazonian pastures. Aust. J. Soil Res., 43, 319-326.

Jordán, A., Zavala, L.M., Mataix-Solera, J., Nava, A.L., Alanís, N., 2011. Effect of fire severity on water repellency and aggregate stability on Mexican volcanic soils. Catena, 84, 136147. 
Keizer, J.J., Doerr, S.H., Malvar, M.C., Ferreira, A.J.D., Pereira, V.M.F.G., 2007. Temporal and spatial variations in topsoil water repellency throughout a crop-rotation cycle on sandy soil in north-central Portugal. Hydrol. Process., 21, 2317-2324.

Kemper, W.D., Chepil, W.S. 1965. Size distribution of aggregates. In: Black, C.A. (Ed.): Methods of Soil Analysis, Part I. American Society of Agronomy, Madison, WI, pp. 499-510.

Klute, A., Dirksen, C., 1986. Hydraulic conductivity and diffusivity: laboratory methods. In: Klute, A. (Ed.): Methods of Soil Analysis. Part 1. Physical and Mineralogical Methods. 2nd ed. ASA/SSSA Monograph 9(1), Madison, WI, pp. 687-732.

Kodešová, R., Rohošková, M., Žigová, A., 2009. Comparison of aggregate stability within six soil profiles under conventional tillage using various laboratory tests. Biologia, 64, $550-554$.

Lal, R., 2011. Organic matter, effects on soil physical properties and processes. In: Glinski J., Horabik J., Lipiec J. (Eds.): Encyclopedia of Agrophysics. Springer, Dordrecht, pp. 528534.

Lamparter, A., Bachmann, J., Deurer, M., Woche, S.K., 2010. Applicability of ethanol for measuring intrinsic hydraulic properties of sand with various water repellency level. Vadose Zone J., 9, 445-450.

Le Bissonnais, Y., 1996. Aggregate stability and assessment of soil crustability and erodibility: I. Theory and methodology. Eur. J. Soil. Sci., 47, 425-443.

Leelamanie, D.A.L., 2014. Initial water repellency affected organic matter depletion rates of manure amended soils in Sri Lanka. J. Hydrol. Hydromech., 62, 309-315.

Lichner, L., Holko, L., Zhukova, N., Schacht, K., Rajkai, K., Fodor, N., Sándor, R., 2012. Plant and biological soil crust influence the hydrophysical parameters and water flow in an aeolian sandy soil. J. Hydrol. Hydromech., 60, 309-318.

Lichner, L., Hallett, P.D., Drongová, Z., Czachor, H., Kovacik, L., Mataix-Solera, J., Homolák, M., 2013. Algae influence hydrophysical parameters of a sandy soil. Catena, 108, 5868.

Madsen, M.D., Zvirzdin, D.L., Petersen, S.L., Hopkins, B.G., Roundy B.A., Chandler, D.G., 2011. Soil water repellency within a burned piñon-juniper woodland: spatial distribution, severity, and ecohydrologic implications. Soil Sci. Soc. Am. J., 75, 1543-1553.

Müller, M., Deurer, M., 2011. Review of the remediation strategies for soil water repellency. Agric. Ecosyst. Environ., 144, 208-221.

Nesper, M., Bünemann, E.K., Fonte, S.J., Rao, I.M., Velásquez, J.E., Ramirez, B., Hegglin, D., Frossard, E., Oberson, A., 2015. Pasture degradation decreases organic $P$ content of tropical soils due to soil structural decline. Geoderma, 257258, 123-133.

Orfánus, T., Bedrna, Z., Lichner, L., Hallett, P.D., Kn̆ava, K., Sebín̆, M., 2008. Spatial variability of water repellency in pine forest soil. Soil \& Water Res., 3, Special Issue 1, S123S129.
Orfánus, T., Dlapa, P., Fodor, N., Rajkai, K., Sándor, R., Nováková, K., 2014. How severe and subcritical water repellency determines the seasonal infiltration in natural and cultivated sandy soils. Soil \& Tillage Research, 135, 49-59.

Pekárová, P., Pekár, J., Lichner, L., 2015. A new method for estimating soil water repellency index. Biologia, 70, 14501455.

SAS Institute, 2004. SAS User's Guide: Statistics. Ver. 9. SAS Institute Inc., Cary, N.C.

Sepehrnia, N., Mahboubi, A.A., Mosaddeghi, M.R., Safari Sinejani, A.A., Khodakaramian, G., 2014. Escherichia coli transport through intact gypsiferous and calcareous soils during saturated and unsaturated flows. Geoderma, 217-218, 83-89.

Sepehrnia, N., Hajabbasi, M.A., Afyuni, M., Lichner, L., 2016. Extent and persistence of water repellency in two Iranian soils. Biologia, 71, 10, 1137-1143.

Shaver, T., 2010. Crop residue and soil physical properties. In: Proc. 22nd Annual Central Plains Irrigation Conference, Kearney, NE, USA, pp. 22-27.

Soil Survey Division Staff, 1993. Soil survey manual. Soil Conservation Service. U.S. Department of Agriculture Handbook 18, 437 p.

Täumer, K., Stoffregen, H., Wessolek, G., 2005. Determination of repellency distribution using soil organic matter and water content. Geoderma, 125, 107-115.

Tillman, R.W., Scotter, D.R., Wallis, M.G., Clothier, B.E., 1989. Water-repellency and its measurement by using intrinsic sorptivity. Aust. J. Soil Res., 27, 637-644.

Urbanek, E., Horn, R., Smucker, A.J.M., 2014. Tensile and erosive strength of soil macro-aggregates from soils under different management system. J. Hydrol. Hydromech., 62, 324-333.

Vogelmann, E.S., Reichert, J.M., Prevedello J., Awe G.O., Mataix-Solera, J., 2013. Can occurrence of soil hydrophobicity promote the increase of aggregates stability? Catena, 110, 24-31.

Walkly, A., Black, I.A. 1934. An examination of the Degtjareff method for determining soil organic matter, and a proposed modification of the chromic acid titration method. Soil Science, 37, 29-38.

Wallis, M.G., Horne, D.J., 1992. Soil water repellency. In: Stewart B.A. (Ed.): Advances in Soil Science, Vol. 20. Springer, New York, pp. 91-146.

WRB, 2014. World Reference Base for Soil Resources 2014. 2nd edition. World Soil Resources Reports No. 106. FAO, Rome.

Zamani, J., Afyunia, M., Sepehrnia, N., Schulin, R., 2016. Opposite effects of two organic wastes on the physical quality of an agricultural soil. Arch. Agron. Soil Sci., 62, 3, 413-427.

Received 18 September 2015 Accepted 27 July 2016 